\title{
Chemosuppressive activities in in vivo studies of Plasmodium falciparum - infected mice using isolated oil of Stigmaphyllon ovatum (Amazon vine) Cav.
}

\author{
Osaro IYEKOWA ${ }^{1, *}$ and Mary Olire EDEMA ${ }^{2}$ \\ ${ }^{I}$ Department of Chemistry, Faculty of Physical Sciences, University of Benin, Benin City, Nigeria \\ ${ }^{2}$ Department of Chemistry, Federal University of Petroleum Resources, Efurun, Warri, Delta State, \\ Nigeria
}

\begin{abstract}
Problem: In sub-Saharan Africa, malaria remains one of the leading health problems. This situation has been aggravated by the increasing spread of drug-resistant Plasmodium falciparum strains. The study was conducted to determine the chemosuppressive activities in in vivo studies of Plasmodium falciparum-infected mice with isolated oil of Stigmaphyllon ovatum leaves used in the traditional treatment of malaria in Nigeria. Methodology: The plant leaves were collected, dried, pulverized and extracted in Soxhlet extractor with hexane solvent. The crude extract was concentrated using a rotary evaporator and phytochemical screening performed using standard methods. Isolation of oil from hexane extract was done using vacuum liquid chromatography while characterization was done by gas chromatography-mass spectrometry (GC-MS). Chemosuppressive activities were conducted along with quinine to determine the antimalarial potency in Plasmodium falciparum- infected BALB/c albino mice. Findings: Glycosides, saponins, phenolics, and alkaloids among others were present. Components detected from the isolated yellow oil of S. ovatum were 9-octadecenoic acid (oleic acid) (Rt:20.0, $19.37 \%$ ), an unsaturated fatty acid, squalene (Rt:25.6, 4.58\%), a terpene; 7-tetradecenal (Rt:22.6, 2.40\%), an aldehyde and alicyclic compounds like bicycle $(3,10)$ hexan-3-one (Rt:16.7, $0.22 \%$ ). Quinine-treated mice exhibited the lowest parasite counts of $0.27 \pm 0.01$ (83.82\% mean chemosuppression) at day 4 of therapy while the lowest parasite counts for the isolated oil was $0.95 \pm 0.05$ (42.92\% mean chemosuppression) at day 4 of therapy. Conclusion: The chemosuppressive activities revealed that the isolated oil exhibit significant suppression $(\mathrm{P}<0.05)$ of Plasmodium falciparum when compared with the standard, quinine which was evident by the photomicrograph results. This work corroborates the local use of the plants for the treatment of malaria in Southern Nigeria.
\end{abstract}

Keywords: Stigmaphyllon ovatum, Plasmodium falciparum, oil, GC-MS.

\section{Introduction}

Malaria is one of the most important parasitic diseases in the world. As a vector-born infectious disease caused by protozoan Plasmodium parasites, it is widespread mainly in tropical and subtropical regions of the world. Each year, there are approximately 515 million cases of malaria, killing between one and three million people, the majority of whom are young children in sub-Saharan Africa [1]. In Nigeria, over 100 million people are at risk of malaria every year and its estimated that about 50 percent of the adult population experience at least one episode of the disease yearly while children of under five years old have up to 2 to 4 attacks of the disease annually [2]. Fevers have always haunted mankind and several ingenious remedies were tried to combat the fevers. Infection often peaks during the rainy season, and higher rates of bedridden workers affect the agricultural productivity of families, communities, and nations. This made the disease to be associated with poverty and regarded as a major hindrance to economic development [3]. In Nigeria, Stigmaphyllon ovatum (Fig. 1) leaves decoction is drunk to treat malaria, fevers, stomach ache, and particularly as an aid to reduce excessive abdominal heat in pregnant women [4].

In Madagascar, inhalation of steam from the decoction of S. ovatum is used as a febrifuge (feverreducing) [5].

In Nigeria in the past decades, malaria cases have been aggravated by the increasing spread of drugresistant Plasmodium falciparum strains and this continuing threat to Africans (the Black people) by this tropical disease lends urgency to the need to expand the systematic exploration of medicinal plants in the search of new bioactive molecules (drugs) or their precursors. The study was conducted to determine the chemosuppressive activities in in vivo studies of Plasmodium falciparum-infected mice with isolated oil of Stigmaphyllon ovatum leaves used in

*Corresponding author: Osaro.iyekowa@uniben.edu 
the traditional treatment of malaria among rural dwellers in Southern Nigeria.

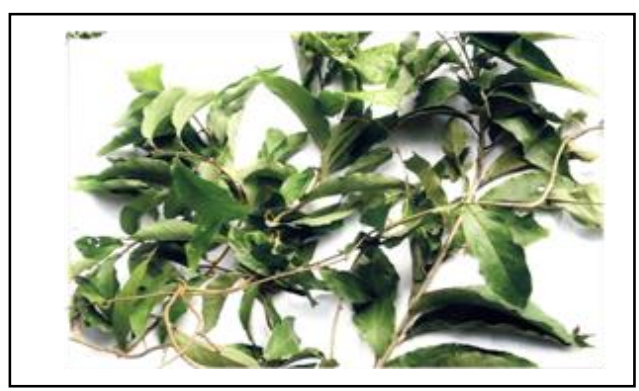

Figure 1. Stigmaphyllon ovatum

\section{Materials and methods}

\subsection{Extraction and treatment of plant sample}

The fresh leaves of Stigmaphyllon ovatum were collected from its natural habitat in Evbuotubu village (Egor Local Government Area) in Edo State, Nigeria. The plant was identified and authenticated by a taxonomist Prof. J. F. Bamidele, with herbarium voucher number (UBHm 0192) deposited in the Department of Plant Biology and Biotechnology, University of Benin, Benin City, Nigeria.

Two hundred and fifty grams $(250 \mathrm{~g})$ of the powdered leaves were extracted with $n$-hexane (Merck, Germany) in a Soxhlet apparatus for 8 hours. The crude extract was dried with $\mathrm{Na}_{2} \mathrm{SO}_{4}$ (Vickers, England) and then concentrated in a rotary evaporator.

\subsection{Phytochemical screening of hexane extract}

Phytochemical screening was done to find the presence of the active chemical constituents such as alkaloids, glycosides, steroids, flavonoids, saponins, terpenoids, phenolics, tannins and eugenols by using the standard procedures [6] and [7].

\subsection{Isolation of oil}

Thirty grams $(30 \mathrm{~g})$ of the crude extract were partitioned with $100 \mathrm{~mL}$ of hexane:methanol (Fisher Scientific, UK) mixture (ratio: 3:2) and shaken vigorously in a separatory funnel. The upper hexane fraction was separated, concentrated and then subjected to vacuum liquid chromatography (VLC), using silica gel (particle size: 200-425 mesh) as the solid phase and hexane: methanol mixture $(4: 1)$ as the mobile phase. A yellow oily phase obtained was dried over $\mathrm{Na}_{2} \mathrm{SO}_{4}$ and concentrated to recover the pure oil (1.6 $\mathrm{mL}$ by volume: yield $5.3 \%$ ), labeled SOHVLC2 (Stigmaphyllon ovatum hexane fraction 2 from vacuum liquid chromatography).

\subsection{GC-MS analysis}

The analysis was carried out on a GC-Mass spectrometer (QP2010 Plus, Shimadzu, Japan) filled with an HP-5 MS (5\% phenysiloxane) column at a temperature programmed at $70{ }^{\circ} \mathrm{C}$ (2 minutes) increase at $10{ }^{\circ} \mathrm{C} / \mathrm{min}$ to $280{ }^{\circ} \mathrm{C}$ and held for 7 minutes. The carrier gas was nitrogen and flow rate, $1.80 \mathrm{~mL} / \mathrm{min}$.

\subsection{Toxicity test}

Albino mice $(21-32 \mathrm{~g})$ of either sex were divided into six independent experimental groups ( 5 mice per groups) and varying doses of the test samples of 10 $\mathrm{mg} / \mathrm{kg}, 20 \mathrm{mg} / \mathrm{kg}, 40 \mathrm{mg} / \mathrm{kg}, 80 \mathrm{mg} / \mathrm{kg}$, and 160 $\mathrm{mg} / \mathrm{kg}$ as well as their control (normal saline; 5 $\mathrm{mL} / \mathrm{kg}$ ) were each administered orally into each of the mice in each of the six groups [8]. Acute toxicity test was used to estimate the lethal dose $\left(\mathrm{LD}_{50}\right)$ of the samples before the antimalarial analysis (using $P$. falciparum-infected mice).

\subsection{Chemosuppressive activities (Antimalarial chemotherapy)}

Development of experimental humanized mouse model:

- Mice: BALB/c mice weighing 20 - 33 g were used. They were housed in standard mosquito-netted metal cages under standard conditions of light and temperature and were maintained on a standard diet and water ad libitum. They were acclimatized for 14 days and were treated in accordance with guidelines for animal care approved by the Animal Ethics Committee of the University of Benin, Benin City, Nigeria.

- Modification of mice: The BALB/c mice were modified by using pharmacological compounds (4 $\mathrm{mg}$ aspirin/kg body weight and $4 \mathrm{mg}$ anhydrous doxycycline eq./kg body weight) to retard their innate immune responses [9 - 11] followed by engraftment of human blood [11] and [12].

Infection of experimental humanized mouse model with Plasmodium falciparum:

- Thirty humanized BALB/c mice were divided into six experimental groups with each group having 5 mice. One of the experimental groups represented the control group, while the remaining experimental groups represented the test groups. The 25 humanized mice in the test groups were inoculated with clinical isolates of $P$. falciparum that had been previously cultured in vitro $[13,14]$ to obtain the parasite density $(8 \%)$ required for inducing in vivo infection, while the 5 humanized mice in the control group were not inoculated with $P$. falciparum.

2.7. Antimalarial chemotherapy of the P. falciparuminfected mouse model with isolated oil S. ovatum

$P$. falciparum-infected humanized immunosuppressed mice were employed to verify the antimalarial principles of each of the test samples. The mice were divided into 5 independent experimental groups (5 mice per group). The negative control drug - dimethyl sulfoxide (DMSO) (4 mg/kg body weight administered three time daily for four days) and positive control drug-quinine $(73 \mathrm{mg} / \mathrm{kg}$ body weight administered three times daily for four days) were used to treat mice in two of the experimental groups (antimalarial validation). The mice received these drugs orally via a gastric 
cannular. Varying doses of the test oil were used to treat the mice in the other three experimental groups. The test samples were administered, by taking into consideration their $\mathrm{LD}_{50}$ values. Mice on isolated oil (SOHVLC 2) received varying doses of 10, 20, 40, 80 , and $160 \mathrm{mg} / \mathrm{kg}$ body weight once daily for four days.

During the course of treatment, postmortem was done on the infected mice that died, according to the procedure of [15], and extracted cardiac blood materials from the inner muscles were hematologically stained and examined for $P$. falciparum parasites, according to the methods of [16]. Parasitaemia was also expressed as a percentage of red blood cells infected, in accordance to the assertion of [17], who stated that a $1 \%$ parasitaemia represented 50,000 parasites $/ \mu \mathrm{L}$ of blood

Upon administration of quinine, DMSO, and the plant oil; parasite densities, haematocrit, as well as total leukocyte counts, were obtained from mice that either died or survived during the chemotherapy phase, according to the methods stated by [16]. Net mean chemosuppression [18] due to drug/extracts administration was calculated according to the formula:

Net mean chemosuppression $(\%)=$

$$
=\frac{100(A-B)}{A}-M C_{0}
$$

where:

$A=$ percentage of parasitaemia in the mice administered with DMSO;

$B=$ percentage of parasitaemia in mice treated with quinine/plant extracts;

$\frac{100(A-B)}{A}=$ mean chemosuppression;

$M C_{0}=$ mean chemosuppression obtained from

mice at day 0 of treatment.

\subsection{Data analysis}

Mean values were expressed as mean and standard error of the mean. Chi-square test were used to determine the level of significance, and $P$-value less than $0.05(P<0.05)$ were considered significant. The software SPSS version 16 was employed for the data analysis.

\section{Results and Discussion}

Table 1. Phytochemical screening of hexane extract of $S$. ovatum

\begin{tabular}{|c|c|c|c|}
\hline S/N & $\begin{array}{c}\text { Phytochemical } \\
\text { constituents }\end{array}$ & $\begin{array}{c}\text { Name of the } \\
\text { test }\end{array}$ & $\begin{array}{c}\text { Hexane } \\
\text { extract }\end{array}$ \\
\hline 1 & Glycosides & General Test & ++ \\
\hline 2 & Saponin & Foam Test & + \\
\hline 3 & Flavonoid & $\begin{array}{c}\text { Lead acetate } \\
\text { Test }\end{array}$ & + \\
\hline 4 & Phenolics & Ferric chloride & + \\
\hline 5 & Tannin & Ferric chloride & - \\
\hline 6 & Eugenol & KOH/HCl & + \\
\hline
\end{tabular}

\begin{tabular}{|c|c|c|c|}
\hline S/N & $\begin{array}{c}\text { Phytochemical } \\
\text { constituents }\end{array}$ & $\begin{array}{c}\text { Name of the } \\
\text { test }\end{array}$ & $\begin{array}{c}\text { Hexane } \\
\text { extract }\end{array}$ \\
\hline 7 & Steroid & $\begin{array}{c}\text { Acetic } \\
\text { acid/ } \mathrm{H}_{2} \mathrm{SO}_{4}\end{array}$ & + \\
\hline 8 & Terpenes & Salkowski Test & + \\
\hline 9 & Alkaloids & Picric acid Test & + \\
\hline
\end{tabular}

Where: $-=$ absent,$+=$ present,$++=$ largely present.

\subsection{GC-MS analysis}

The GC-MS chromatogram of the isolated yellow oil given in Fig. 2 showed 22 peaks indicating from the search list of the chemical abstract service twentytwo compounds. The chemical compounds identified in the oil fraction are presented in Table 2.

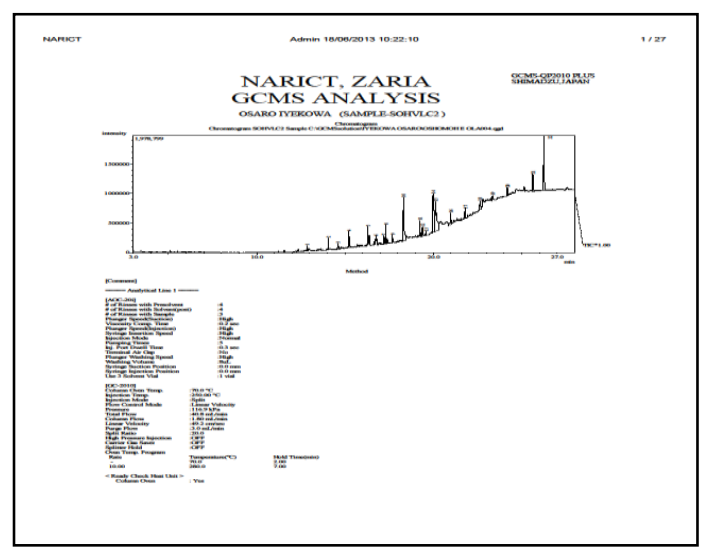

Figure 2. GC-MS analysis of isolated oil of $S$. ovatum.

Table 2. GC-MS analysis of isolated yellow oil of $S$. ovatum.

\begin{tabular}{|c|c|c|c|}
\hline $\begin{array}{c}\text { Peak } \\
\text { No. }\end{array}$ & $\begin{array}{c}\text { Retention } \\
\text { time (Rt) }\end{array}$ & Name of compound & $\begin{array}{c}\text { Area } \\
\text { percent } \\
(\boldsymbol{\%})\end{array}$ \\
\hline 1 & 12.8 & 2,3,6-trimethyl decane & 0.98 \\
\hline 2 & 14.1 & 2-methyl decane & 1.82 \\
\hline 3 & 14.6 & 2-methyl decane & 1.55 \\
\hline 4 & 15.2 & Heptadecane & 2.89 \\
\hline 5 & 16.3 & $\begin{array}{c}\text { 3-methyl-5-propyl } \\
\text { nonane }\end{array}$ & 1.70 \\
\hline 6 & 16.7 & $\begin{array}{c}\text { Bicycle (31,0) hexan- } \\
\text { 3-one (thujone) }\end{array}$ & 0.22 \\
\hline 7 & 17.2 & $\begin{array}{c}\text { 2,6,6-trimethylbicyclo } \\
\text { (3,1,1)heptanes }\end{array}$ & 2.15 \\
\hline 8 & 17.3 & Heptadecane & 3.05 \\
\hline 9 & 17.7 & $\begin{array}{c}\text { Hexadecanoic acid } \\
\text { (palmitic acid) }\end{array}$ & 1.45 \\
\hline 10 & 18.3 & $\begin{array}{c}\text { 2-propyl pentadecyl } \\
\text { ester }\end{array}$ & 14.79 \\
\hline 11 & 19.2 & Heptadecane & 0.43 \\
\hline 12 & 19.4 & $\begin{array}{c}\text { 6-octadecenoic methyl } \\
\text { ester }\end{array}$ & 2.74 \\
\hline 13 & 19.6 & $\begin{array}{c}\text { Hepatacosanoic acid, } \\
\text { methyl ester }\end{array}$ & 0.99 \\
\hline 14 & 20.0 & 9-octadecenoic acid & 19.37 \\
\hline 15 & 20.1 & Heptadecane & 15.03 \\
\hline 16 & 21.0 & Heptadecane & 3.80 \\
\hline 17 & 21.8 & Tetracontane & 2.40 \\
\hline 18 & 22.6 & 7-tretradecenal & 2.40 \\
\hline 19 & 23.4 & Hexadecane & 0.96 \\
\hline
\end{tabular}




\begin{tabular}{|c|c|c|c|}
\hline $\begin{array}{c}\text { Peak } \\
\text { No. }\end{array}$ & $\begin{array}{c}\text { Retention } \\
\text { time (Rt) }\end{array}$ & Name of compound & $\begin{array}{c}\text { Area } \\
\text { percent } \\
(\mathbf{\%})\end{array}$ \\
\hline 20 & 24.2 & 8-hexylpentadecane & 1.58 \\
\hline 21 & 25.6 & Squalene & 4.58 \\
\hline 22 & 26.3 & Tetracontane & 15.05 \\
\hline Total & & 100.00 \\
\hline
\end{tabular}

From Table 2, major components detected from the isolated yellow oil of $S$. ovatum are 9octadecenoic acid (oleic acid) (Rt:20.0, 19.37\%), an unsaturated fatty acid; tetracontane (Rt:26.3, $15.05 \%)$, heavy molecular weight alkane; heptadecane (Rt:20.1, 15.03\%) a high molecular weight alkane while minor components among others were squalene (Rt:25.6, 4.58\%), a terpene; 7tetradecenal (Rt:22.6, 2.40\%), an aldehyde and alicyclic compounds like bicycle $(3,10)$ hexan-3-one (Rt:16.7, 0.22\%), thujone and 2,6,6-trimethylbicyclo $(3,1,1)$ heptane (Rt:17.2, 2.15\%). The result indicated that the hexane extract constitutes important phytochemicals like terpenes, saponins, phenolics and alkaloids (Table 1) which have physiological effects on man. The presence of oleic acid (an unsaturated fatty acid) as indicated by the GC-MS analysis also suggests that the oil can form high molecular weight esters.

\subsection{Toxicity test results}

The acute toxicity test used to estimate the $\mathrm{LD}_{50}$ values of the isolated yellow oil of Stigmaphyllon ovatum involves six independent experimental groups (5 mice per group) with one group as control.

The results of the toxicity test are presented in Fig. 3.

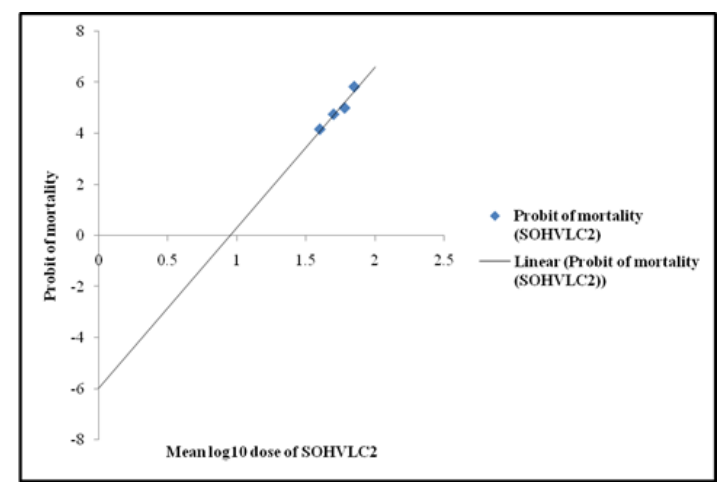

Figure 3. Probit regression graph of the toxicity of SOHVLC2.

LD50 value $=$ antilog of the value of concentration of the extract that correlates with a probit value of 5; LD50 of SOHVLC2 $=\operatorname{antilog}(1.75)=56.23 \mathrm{mg} / \mathrm{kg}$. Mice in the experimental groups that received 10, 20 and $40 \mathrm{mg}$ of SOHVLC $2 / \mathrm{kg}$ body weight had no probit value because no death was recorded; No probit values were also recorded in the experimental groups of mice which were administered with 80 and $160 \mathrm{mg}$ SOHVLC2/kg body weight because all the mice in these experimental groups died.

\subsection{Antimalarial chemotherapy}

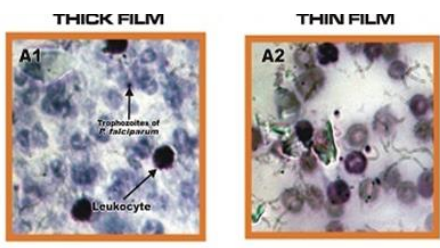

A: Cardiac blood film of a malaria-infected sub-chronic immunosuppressed mouse at the end of treatment with quinine

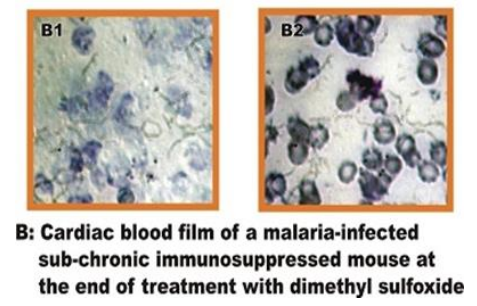

Figure 4. Post-mortem examination of peripheral blood of sub-chronic immunosuppressed mice after treatment with dimethyl sulfoxide and quinine (Giemsa, × 1000).

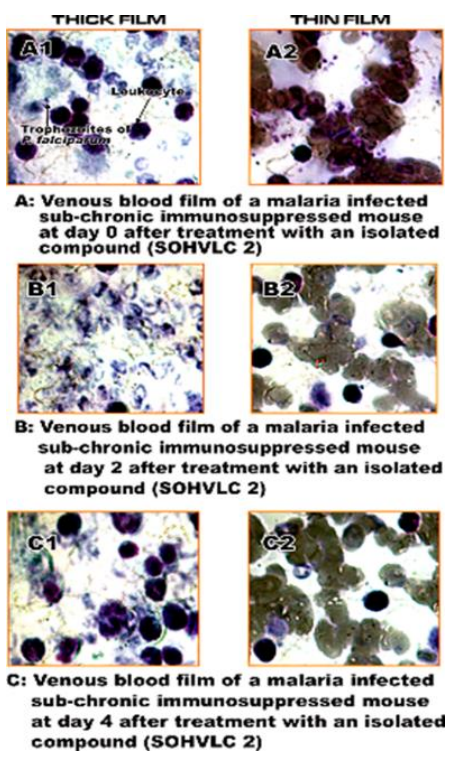

Figure 5. Peripheral blood of sub-chronic immunosuppressed mice after treatment the plant oil (SOHVLC2) (Giemsa, × 1000).

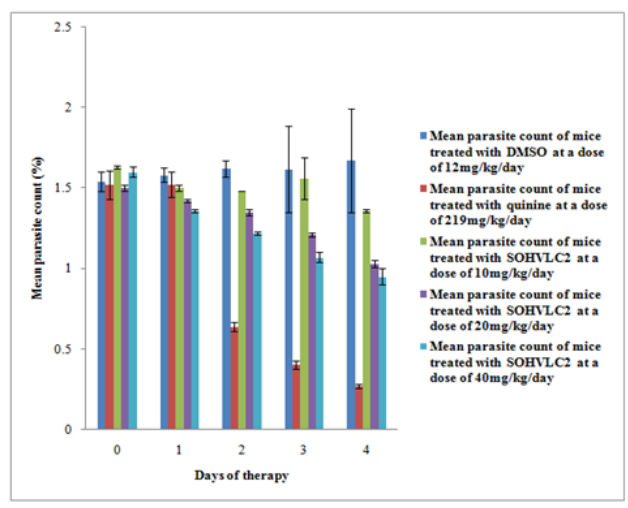

Figure 6. $P$. falciparum densities obtained from quinine-validated infected mice treated with the plant oil (SOHVLC 2). 
Table 3. Chemosuppressive activities of isolated oil obtained from $S$. ovatum extract against P. falciparum

\begin{tabular}{|c|c|c|c|c|c|c|}
\hline \multirow{2}{*}{$\begin{array}{l}\text { Days of } \\
\text { therapy }\end{array}$} & \multirow{2}{*}{$\begin{array}{c}\text { Experimental } \\
\text { groups of } \\
\text { mice }\end{array}$} & \multirow{2}{*}{$\begin{array}{c}\text { Dose of } \\
\text { therapeutic } \\
\text { agents given }\end{array}$} & \multicolumn{2}{|c|}{ Mean parasite counts } & \multirow{2}{*}{$\begin{array}{l}\text { MCS } \\
(\%)\end{array}$} & \multirow{2}{*}{$\begin{array}{l}\text { NCS } \\
(\%)\end{array}$} \\
\hline & & & $\left(\times 10^{3}\right.$ cells $\left./ \mu \mathrm{L}\right)$ & $(\%)$ & & \\
\hline \multirow[t]{5}{*}{0} & NC group & $12 \mathrm{mg} / \mathrm{kg} /$ day & $77.05 \pm 3.18$ & $1.54 \pm 0.06$ & - & - \\
\hline & PC group & $219 \mathrm{mg} / \mathrm{kg} / \mathrm{day}$ & $76.14 \pm 4.45$ & $1.52 \pm 0.09$ & 1.18 & 0 \\
\hline & T1 SOHVLC2 & 10 mg/kg/day & $81.71 \pm 0.47$ & $1.63 \pm 0.01$ & $\{6.06\}$ & 0 \\
\hline & T2 SOHVLC2 & $20 \mathrm{mg} / \mathrm{kg} / \mathrm{day}$ & $75.22 \pm 0.76$ & $1.50 \pm 0.02$ & 2.37 & 0 \\
\hline & T3 SOHVLC2 & $40 \mathrm{mg} / \mathrm{kg} /$ day & $80.04 \pm 1.37$ & $1.60 \pm 0.03$ & $\{3.89\}$ & 0 \\
\hline \multirow[t]{5}{*}{2} & NC group & $12 \mathrm{mg} / \mathrm{kg} /$ day & $80.79 \pm 2.60$ & $1.62 \pm 0.05$ & - & - \\
\hline & PC group & $219 \mathrm{mg} / \mathrm{kg} /$ day & $31.78 \pm 1.28$ & $0.64 \pm 0.03$ & 60.67 & 59.49 \\
\hline & T1 SOHVLC2 & $10 \mathrm{mg} / \mathrm{kg} /$ day & $74.07 \pm 0.16$ & $1.48 \pm 0.00$ & 8.33 & 9.97 \\
\hline & T2 SOHVLC2 & $20 \mathrm{mg} / \mathrm{kg} / \mathrm{day}$ & $67.82 \pm 1.08$ & $1.35 \pm 0.02$ & 16.02 & 13.65 \\
\hline & T3 SOHVLC2 & $40 \mathrm{mg} / \mathrm{kg} / \mathrm{day}$ & $61.17 \pm 0.49$ & $1.22 \pm 0.01$ & 24.29 & 28.17 \\
\hline \multirow[t]{6}{*}{4} & NC group & $12 \mathrm{mg} / \mathrm{kg} / \mathrm{day}$ & $83.58 \pm 15.94$ & $1.67 \pm 0.32$ & - & - \\
\hline & $\mathrm{PC}$ group & $219 \mathrm{mg} / \mathrm{kg} /$ day & $13.52 \pm 0.57$ & $0.27 \pm 0.01$ & 83.82 & 82.65 \\
\hline & $\mathrm{T} 1$ & & & & & \\
\hline & $\begin{array}{l}\text { SOHVLC2 } \\
\text { T2 }\end{array}$ & $10 \mathrm{mg} / \mathrm{kg} /$ day & $68.15 \pm 0.30$ & $1.36 \pm 0.01$ & 18.46 & 24.51 \\
\hline & $\begin{array}{l}\text { SOHVLC2 } \\
\text { T3 }\end{array}$ & $20 \mathrm{mg} / \mathrm{kg} /$ day & $51.32 \pm 1.16$ & $1.03 \pm 0.02$ & 38.61 & 36.24 \\
\hline & SOHVLC2 & $40 \mathrm{mg} / \mathrm{kg} /$ day & $47.71 \pm 2.37$ & $0.95 \pm 0.05$ & 42.92 & 46.80 \\
\hline
\end{tabular}

MCS indicates mean chemo suppression; NCS indicates net mean chemo suppression; NC indicates the negative control group of P. falciparum-infected mice which received dimethyl sulfoxide; PC indicates the positive control group of P. falciparuminfected mice which were administered with quinine; T1 SOHVLC2, T2 SOHVLC2, and T3 SOHVLC2 indicate the three experimental groups of $P$. falciparum-infected mice which were administered with varying doses of $S$. ovatum isolated oil, * means that values obtained were apparently recorded as zero because all the mice in the respective experimental group had died prior to the day of therapy.

According to the report of [11], in vitro culture $P$. falciparum-infected human blood sample when scientifically conducted normally show exponential proliferation of the parasites after 92 hours incubation. In this work, the test animals (mice) were inoculated with clinical isolates of $P$. falciparum that had been previously cultured before treatment commenced.

At the end of treatment of the infected mice with quinine and DMSO respectively, post-mortem evaluation of the parasitological responses in the peripheral blood of the mice were also conducted, as shown in the photomicrographs displayed in Fig. 4A, 4B. The photomicrograph of quinine-treated mice showed an absence of knobs on the surface of their erythrocytes, with a relatively low parasitaemia (Fig. 4A); when compared to the photomicrograph of DMSO-treated mice (Fig. 4B) that showed a proliferation of knobs, produced by the sequestered $P$. falciparum over the surface of their host erythrocytes, with a relatively high level of parasitaemia. From Fig. 5 there was a progressive significant reduction in $P$. falciparum parasites from the test oil (plant) sample

Parasite suppression upon therapy with varying doses of the isolated oil was compared with suppression obtained from treatment with quinine (Fig. 6). All the doses of the oil (SOHVLC 2) derived from $S$. ovatum exhibited largely significant suppression $(\mathrm{P}<0.05)$ of $P$. falciparum parasites in $P$. falciparum-infected mice when their chemosuppression values were compared to those recorded in the quinine-treated $P$. falciparuminfected mice.

Table 3 represents the chemosuppressive activities obtained during therapy of $P$. falciparuminfected mice with the test oil sample (isolated from $S$. ovatum) and positive control (quinine). Quininetreated mice exhibited the lowest parasite counts (mean parasite counts at day 4 of therapy was estimated at $0.27 \pm 0.01 \%$ ), while the lowest parasite counts for SOHVLC2 was recorded in the mice treated with $40 \mathrm{mg} / \mathrm{kg}$ body weight/day at day 4 of therapy (mean parasite counts of SOHVLC 2 at day 4 of therapy, $0.95 \pm 0.05 \%$ ) while the net mean chemosuppression was $46.80 \%$

\section{Conclusions}

The antimalarial results indicated that isolates SOHVLC2 (yellow oil) from S. ovatum demonstrated significant suppression against $P$. falciparuminfected parasites in mice. Further research is being advocated especially in spectroscopic characterization and structural elucidation of the isolated oil. 


\section{Conflict of interest}

The authors declare no conflict of interest.

\section{Acknowledgement}

The authors are grateful to Mr. Odaro Stanley Imade and Osamwonyi Igbinuwen of the Department of Biological Sciences, Igbinedion University, Okada (IUO) and Haematology Department, Medical Laboratory Services, University of Benin Teaching Hospital (UBTH), Edo State respectively for their technical assistance.

\section{References}

[1]. D.A. Joy, X. Feng1, J. Mu, T. Furuya, K. Chotivanich, A.U. Krettli, M. Ho, A. Wang, N. J. White, Edward Suh, Peter Beerli, X. Su, Early origin and recent expansion of Plasmodium falciparum, Science 300 (2003) 318. DOI: $10.1126 /$ science. 1081449

[2]. FMOH. National Antimalarial Treatment Guidelines. Federal Ministry of Health, National Malaria and Vector Control Division, Abuja-Nigeria.25 (2005).

[3]. K.G. Kuhn, D.H. Campbell-Lendrum, B. Armstrong, C.R. Davies, Malaria in Britain: past, present and the future. Proc. Natl. Acad. Sci. 100 (2003) 9997.

DOI: $10.1073 /$ pnas. 1233687100

[4]. F. Olojo. (Personal Communication dated $7^{\text {th }}$ May (2006).

[5]. P. Rasoanaivo, A. Petitjean, S. Manga-Urverg, A. Rakoto Ratsimamanga, Medicinal Plants used to treat malaria in Madagascar, J. Ethnopharmacol. 2 (1992) 117. DOI: 10.1016/0378-8741(92)90070-8

[6]. C.K Kokate, A.P. Purohit, and S.B. Gokhale. Pharmacognosy, Published by Nirali Prakashan, Pune, pp. 616 - 617 (2009).

[7]. W.C Evans and G.E Trease, Pharmacognosy, Published by W.B. Saunders, Edinburgh, pp. 193 - 407 (2002).

[8]. D. Lorke, A new approach to practical acute toxicity test, Arch. Toxicol. 54 (1983) 275. DOI: $10.1007 / \mathrm{BF} 01234480$
[9]. A. Javeed, Y. Hou, K. Duan, B. Zhang, H. Shen, Y. Cao, Y. Zhao, Aspirin significantly decreases the nonopsonic phagocytosis and immunogenicity of macrophages in mice, Infl. Res. 60 (2011) 389. DOI: $10.1007 / \mathrm{s} 00011-010-0283-4$

[10]. A. Bellahsene, A. Forgren, Effect of Doxycycline on immune response in mice, Infect. Immun. 48 (1985) 556.

[11]. O.S. Imade, O. Iyekowa, M.O. Edema, F.I. Akinnibosun, B.H. Oladeinde, M.A. Olley, Cost-effective scheme developed for studying human malaria caused by Plasmodium falciparum, J. Nat. Sci. Res. 2 (2012) 1.

[12]. A. Moreno, E. Badell, N. Van-Rooijen, P. Druilhe, Human malaria in ummunocompromised mice: New in vivo model for chemotherapy studies, Antimicrob. Agents Ch. 45 (2001) 1847.

Doi:10.1128/AAC.45.6.1847-1853.2001

[13]. W. Trager, J.B. Jensen, Human malaria parasites in continuous culture, Science 93 (1976) 673.

[14]. C. Lambros, J. Vanderberd, Synchronization of $P$. falciparium erythrocyte stages in culture, $\mathrm{J}$. Parasitol. 65 (1979) 418.

[15]. O.W. Schlam, N.C. Jain, E.J. Carroll, Veterinary Hematology, $3^{\text {rd }}$ Edition, Lea\&Fibinger Publisher, USA, 207-209 (1975).

[16]. WHO. Basic Malaria Microscopy Part 1. Learner's Guide, $2^{\text {nd }}$ Edition, WHO Press, Geneva, 21 - 68, (2009).

[17]. A. Moody, Rapid diagnostic tests for malaria parasites, Clin. Microbiol. Rev. 15 (2002) 66. DOI: 10.1128/CMR.15.1.66-78.2002

[18]. A.S. Bassey, J.E. Okokon, E.I. Etim, F.U. Umoh, E. Bassey, Evaluation of the in vivo antimalarial activity of ethanolic leaf and stembark extracts of Anthocleista djalonenis, Indian J. Pharmacol. 41 (2009) 258.

DOI: $10.4103 / 0253-7613.59924$

Received: 13.11.2016

Received in revised form: 22.01.2017

Accepted: 27.01.2017 